\title{
ANALISIS PENGARUH TEKANAN WAKTU, PROSEDUR REVIU \& KONTROL KUALITAS, PROFESIONAL KOMITMEN, DAN PROFESIONALISME TERHADAP PENGHENTIAN PREMATUR ATAS PROSEDUR AUDIT (STUDI EMPIRIS PADA INTERNAL AUDITOR DI PERUSAHAAN DKI JAKARTA TAHUN 2017)
}

\author{
Yanti \\ Fakultas Ekonomi Universitas Tarumanagara Jakarta \\ Email: yantiyou@hotmail.com
}

\begin{abstract}
The purpose of this research is to analyze the effect of time pressure, review procedure and quality control, professional commitment, and professionalism on premature termination of audit procedure. The data used in this research were obtained by distribusing questionnaires to the internal auditors who worked for companies in Jakarta. Seven companies were used as samples. The result of this study shows that time pressure has a positive and significant effect on premature termination of audit procedure. On the other hand, review procedure and control quality, professional commitment, and professionalism have negative and but non-significant impact on premature termination of audit procedure.
\end{abstract}

Keywords : Time Pressure, Review Procedure \& Quality Control, Professional Commitment, Professionalism, Premature Termination of Audit Procedures

\begin{abstract}
ABSTRAK
Tujuan penelitian ini adalah untuk menganalisis pengaruh tekanan waktu, prosedur reviu \& kontrol kualitas, profesional komitmen, dan profesionalisme terhadap penghentian prematur atas prosedur audit. Data yang digunakan dalam penelitian ini diperoleh dengan cara menyebarkan kuesioner kepada para internal auditor yang bekerja pada perusahaan di Wilayah DKI Jakarta. Perusahaan yang menjadi sampel penelitian terdiri dari 7 perusahaan. Hasil analisis menunjukkan bahwa tekanan waktu berpengaruh positif dan signifikan terhadap penghentian prematur atas prosedur audit. Sedangkan prosedur reviu \& kontrol kualitas, komitmen professional, dan profesionalisme mempunyai pengaruh negatif dan tidak signifikan terhadap penghentian prematur atas prosedur audit.
\end{abstract}

Kata kunci: Tekanan Waktu, Prosedur Reviu \& Kontrol kualitas, Profesional Komitmen, dan Profesionalisme, Penghentian Prematur atas Prosedur Audit

\section{PENDAHULUAN \\ Latar Belakang}

Globalisasi ekonomi dan kemajuan teknologi telah mendorong kompetisi yang semakin tajam di lingkungan bisnis. Setiap entitas bisnis dipacu untuk selalu melakukan inovasi agar tetap eksis dalam persaingan. Keadaan ini menuntut para pimpinan atau manajemen perusahaan untuk dapat mengelola sumber daya yang dimiliki oleh perusahaan secara lebih efektif untuk mencapai tujuan yang telah ditetapkan sebelumnya selain itu badan usaha dituntut pula memiliki nilai tambah bagi badan usahanya.

Tuntutan atas sistem dan sumber daya manusia yang handal dan memiliki nilai tambah terjadi pula pada bidang auditor internal. Tuntutan ini bertujuan untuk meningkatkan kinerja dan produk yang dihasilkan oleh auditor internal. Auditor internal merupakan suatu aktivitas assurance yang objektif dan konsultasi yang independen, yang dirancang untuk memberi nilai tambah dan memperbaiki operasi suatu perusahaan.

Aktivitas ini membantu organisasi mencapai tujuannya melalui suatu pendekatan yang sistematis dan disiplin untuk mengevaluasi dan memperbaiki efektivitas proses manajemen risiko, kontrol, dan tata kelola. Auditor internal yang handal diharapkan dapat mengambil langkah untuk mengantisipasi setiap tindakan penyimpangan yang mungkin 
terjadi di masa yang akan datang dan mengungkapkannya dalam temuan audit. Audit yang dilakukan oleh auditor internal seharusnya dapat meningkatkan kualitas informasi yang reliable, berkualitas, dan dapat dipertanggungjawabkan keakuratannya. Untuk mencapai hal tersebut maka auditor internal harus melakukan proses audit. Meskipun dalam teori dinyatakan secara jelas bahwa proses audit yang baik adalah audit yang mampu meningkatkan kualitas informasi sekaligus dengan konteks yang terkandung di dalamnya, namun dalam prakteknya terdapat perilaku yang dapat menyebabkan berkurangnya kualitas audit yang dilakukan oleh mereka. Menurut Coram, et al (dalam Mutia, Ratna, dan Choirul, 2010) salah satu bentuk perilaku pengurangan kualitas audit adalah penghentian prematur atas prosedur audit.

Tindakan penghentian prematur atas prosedur audit berkaitan dengan penghentian terhadap prosedur audit yang disyaratkan, tidak melakukan pekerjaan secara lengkap dan mengabaikan prosedur audit. Tindakan ini tentunya disebabkan beberapa faktor yang berasal dari internal yaitu dalam diri auditor internal sendiri maupun eksternal. Menurut Jansen dan Glinow dalam Malone dan Roberts (1996) dalam Suryanita, Doddy, dan Hanung (2007), perilaku individu merupakan refleksi dari sisi personalitasnya dan faktor situasional yang terjadi pada saat itu yang mendorong seseorang untuk membuat suatu keputusan.

\section{Kajian Teori}

Dalam penelitian ini terdiri dari teori-teori yang digunakan untuk mendukung halhal yang dapat mempengaruhi dilakukannya premature sign off of audit procedure. Background theory penelitian ini adalah teori atribusi. Teori atribusi merupakan penjelasan bagaimana cara kita mengetahui dan menentukan apa penyebab serta motif dari perilaku yang lakukan oleh seseorang. Sedangkan, menurut Woolfolk (2007) menyatakan bahwa teori atribusi menjelaskan mengenai bagaimana atribut individu dapat menyebabkan suatu kejadian dan bagaimana persepsi ini dapat mempengaruhi kegunaan mereka didalam organisasi.

Selain teori atribusi penelitian ini juga menggunakan teori etika sebagai grand theory dalam penelitian ini. Etika adalah suatu pendekatan sistematis atas penilaian moral yang didasarkan atas penalaran, analisis, sintesis, dan reflektif (Baron, 2005, h 27 dalam Agoes dan Ardana (2011)). Teori Etika adalah pedoman seseorang dalam melakukan tindakan atau tingkah laku yang baik dalam sudut pandang budaya dan agama. Teori etika ini menyediakan kerangka yang memungkinkan seseorang untuk memastikan apakah tindakan yang dilakukannya telah sesuai dengan etika auditor.

Menurut Arens, Elder, Beasley, dan Hogan (2017, h.28), "Auditing is the accumulation and evaluation of efidence about information to determine and report on the degree of correspondence between the information and established criteria. Auditing should be done by a competent, independent person."

Menurut Nisa (2013) dalam Aini dan Kurnia (2015, h.5) menyatakan bahwa penghentian prematur atas prosedur audit merupakan sebagai suatu praktik yang dilakukan oleh auditor ketika sedang melakukan dokumentasi prosedur audit dengan lengkap tanpa benar-benar melakukannya dan mengabaikannya serta tidak melakukan beberapa prosedur audit yang telah ditetapkan tetapi auditor tersebut tetap dan dapat memberikan kewajaran suatu laporan keuangan.

Menurut Wahyudi, Lucyanda, dan Suhud (2011, h. 5) menyatakan bahwa tekanan waktu merupakan suatu keadaan dimana auditor mendapatkan tekanan (pressure) dari Perusahaan tempat dimana auditor tersebut bekerja. Tekanan tersebut berupa seorang 
auditor diwajibkan dapat menyelesaikan auditnya pada waktu dan anggaran biaya yang telah ditentukan sebelumnya.

Heriyanto (2002) dalam Weningtyas, Setiawan, dan Triatmoko (2006) mendefinisikan prosedur reviu sebagai "pemeriksaan terhadap kertas kerja yang dilakukan oleh auditor pada level tertentu".

Menurut trisnaningsih, 2003 (dalam Wahyudi, Lucyanda, dan Suhud, 2011), komitmen profesional adalah tingkat loyalitas individu pada profesinya seperti yang dipersepsikan oleh individu tersebut.

Profesionalisme menurut Kamus Besar Bahasa Indonesia adalah: "Profesionalisme adalah mutu, kualitas, dan tindak tanduk yang merupakan ciri suatu profesi atau orang yang profesional."

Berikut ini adalah kerangka pemikiran dalam penelitian ini, yaitu:

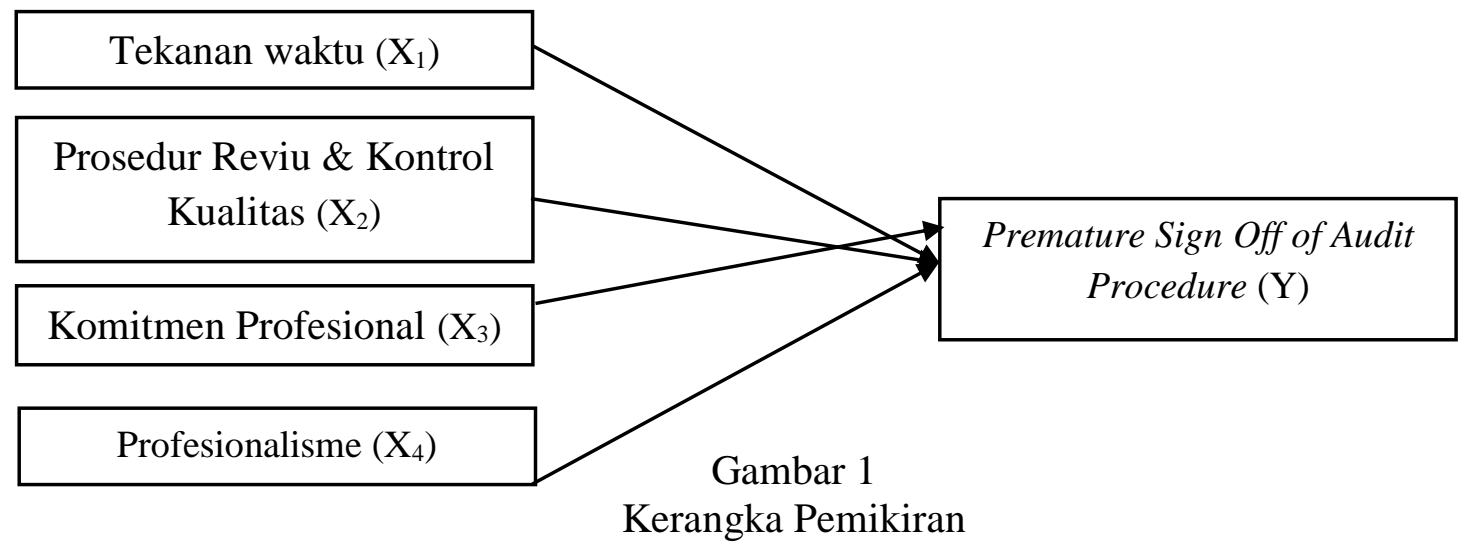

Dari model penelitian di atas, maka dapat diuraikan hipotesis yang akan diuji dalam penelitian ini, yaitu sebagai berikut:

\section{a. Tekanan waktu dengan Penghentian Prematur Prosedur Audit}

Tekanan waktu dapat muncul ketika auditor mendapatkan tekanan dari tempatnya bekerja untuk menyelesaikan pekerjaannya dengan tepat waktu dengan anggaran yang telah ditetapkan sebelum melakukan proses audit. Tekanan waktu ini bertujuan untuk mengurangi beban biaya audit. Dengan adanya tekanan waktu ini memaksa auditor untuk menyelesaikan tugas yang diberikan dengan cepat atau sesuai dengan anggaran waktu yang telah ditetapkan. Hasil audit yang diperoleh ketika adanya ditetapkan tekanan waktu pasti berbeda dengan hasil audit ketika tidak ditetapkannya tekanan waktu. Ketika auditor ingin menepati anggaran waktu yang telah ditetapkan, kemungkinan auditor akan mengabaikan prosedur audit yang telah ditetapkan dan cenderung akan melakukan Penghentian Prematur Prosedur Audit.

Formulasi hipotesis yang diajukan oleh penulis adalah sebagai berikut:

$\mathrm{H}_{1}$ : Tekanan waktu berpengaruh terhadap Penghentian Prematur Prosedur Audit

\section{b. Prosedur Reviu \& Kontrol Kualitas dengan Penghentian Prematur Prosedur Audit}

Prosedur reviu \& kontrol kualitas merupakan pemeriksaan kerja yang dilakukan oleh karyawan pada level tertentu. Apabila Perusahaan menerapkan prosedur reviu \& kontrol kualitas secara efektif, maka semakin kecil kemungkinan auditor untuk melakukan penyimpangan dalam pelaksanaan audit seperti penghentian prematur prosedur audit. Semakin tinggi kemungkinan terdeteksinya praktik penghentian prematur 
REVIU \& KONTROL KUALITAS, PROFESIONAL KOMITMEN,

DAN PROFESIONALISME TERHADAP PENGHENTIAN

PREMATUR ATAS PROSEDUR AUDIT (STUDI EMPIRIS PADA

INTERNAL AUDITOR DI PERUSAHAAN DKI JAKARTA TAHUN 2017)

prosedur audit melalui prosedur reviu \& kontrol kualitas, maka semakin rendah

kemungkinan auditor untuk melakukan praktik ini.

Formulasi hipotesis yang diajukan oleh penulis adalah sebagai berikut:

$\mathrm{H}_{2}$ : Prosedur reviu \& kontrol kualitas berpengaruh terhadap penghentian

prematur prosedur audit

\section{c. Komitmen Profesional dengan Penghentian Prematur Prosedur Audit}

Komitmen dipandang sebagai konstruk multi-dimensi yang terdiri dari affective professional commitment, continuance professional commitment, dan normative professional commitment. Meskipun ketiga dimensi komitmen berbeda, namun pengaruhnya terhadap perilaku audit disfungsional adalah sama, yaitu semakin kuat komitmen profesional yang dimiliki auditor, maka semakin kecil kemungkinan mereka untuk melakukan praktik perilaku audit disfungsional.

Formulasi hipotesis yang diajukan oleh penulis adalah sebagai berikut:

$\mathrm{H}_{3}$ : Komitmen Profesional berpengaruh terhadap penghentian prematur prosedur audit

\section{d. Profesionalisme dengan Penghentian Prematur Prosedur Audit}

Sikap Profesional seorang auditor sangat penting dalam menghasilkan audit yang berkualitas. Hal ini karena auditor akan mengambil keputusan berdasarkan pertimbangan yang dimilikinya. Jika kurangnya sikap professional pada seorang auditor maka ia tidak akan mempertimbangkan suatu keputusan dengan matang sehingga penghentian prematur prosedur audit akan sangat mungkin dilakukan.

Formulasi hipotesis yang diajukan oleh penulis adalah sebagai berikut:

$\mathrm{H}_{4}$ : Profesionalisme berpengaruh terhadap penghentian prematur prosedur audit

\section{METODE PENELITIAN}

Data yang peneliti gunakan dalam penelitian ini yaitu dengan menggunakan data primer, dimana data diperoleh dengan menggunakan kuesioner yang disebarkan ke responden yaitu auditor yang bekerja di Perusahaan wilayah DKI Jakarta baik sebagai staff, supervisor, dan manajer. Populasi dari penelitian ini adalah internal auditor yang bekerja pada Perusahaan yang terletak di wilayah DKI Jakarta pada tahun 2017. Sampel ini diperoleh dari 7 Perusahaan yang terletak di wilayah DKI Jakarta. Teknik pemilihan sampel dilakukan dengan teknik pemilihan purposive sampling, dimana dalam pemilihan sampel disesuaikan dengan beberapa kriteria. Berikut ini kriteria dalam pemilihan sampel: (a) Responden merupakan auditor yang bekerja di perusahaan swasta di wilayah DKI Jakarta tahun 2017 dan bersedia mengisi kuesioner.(b) Kuesioner yang disebar antara 100 kuesioner, (c) Responden memiliki tingkat pendidikan minimal Diploma, (d) Memiliki pengalaman audt minimal dari 1 tahun, (e) Ukuran sampel yang digunakan adalah dari tingkat paling rendah sampai paling tinggi dalam penghentian prematur atas prosedur penghentian premature atas prosedur audit. Jumlah data penelitian berdasarkan kriteria-kriteria dengan melakukan penyebaran kuesioner adalah sebesar 102 kuesioner yang dapat diolah dan telah terisi dengan lengkap.

Operasional variabel terbagi menjadi dua, yaitu variabel dependen dan variabel independen. Dimana variabel dependen yang digunakan dalam penelitian ini adalah premature sign off of audit procedure. Sedangkan variabel independen yang digunakan dalam penelitian ini adalah tekanan waktu, prosedur reviu \& kontrol kualitas, profesional komitmen, dan profesionalisme. 
Data yang terkumpul akan diolah dengan PLS (Partial Least Squares) Versi 3. PLS dapat digunakan untuk mengatasi permasalahan yang terdapat di dalam hubungan antar variabel yang kompleks namun ukuran sampel datanya kecil. Konstrak eksogen memberikan efek kepada konstrak lainnya, sedangkan konstrak endogen merupakan konstrak yang dijelaskan oleh konstrak eksogen (Yamin dan Kurniawan, 2009).

\section{HASIL DAN PEMBAHASAN}

\section{Hasil Uji Statistik}

\section{Uji Validitas}

Uji validitas dalam penelitian ini menggunakan 2 metode, yaitu:

a. Convergent Validity

Convergent Validity digunakan untuk mengukur validitas indikator reflektif sebagai pengukur variabel yang dapat dilihat dari outer loading dari masing-masing indikator variabel. Suatu indikator dikatakan mempunyai reliabilitas yang baik, apabila nilai outer loding di atas 0,70 (Jonathan Sarwono, 2014). Sedangkan nilai outer loading masih dapat ditolerir hingga 0,50 dan dibawah dari nilai 0,50 dapat dihilangkan dari analisis (Ghozali, 2015).

Tabel 1 Nilai Loading factor Konstruk Eksogen Tekanan Waktu, Prosedur Reviu \& Kontrol Kualitas, Komitmen Profesional, Profesionalisme

(Sumber: hasil olah data)

\begin{tabular}{|c|c|c|}
\hline $\begin{array}{l}\text { Konstruk } \\
\text { Eksogen }\end{array}$ & Indikator & $\begin{array}{l}\text { Loading } \\
\text { factor }\end{array}$ \\
\hline \multirow{5}{*}{$\begin{array}{l}\text { Tekanan } \\
\text { Waktu }\end{array}$} & $\mathrm{X} 11$ & 0,895 \\
\hline & $\mathrm{X} 12$ & 0,899 \\
\hline & $\mathrm{X} 13$ & 0,916 \\
\hline & X14 & 0,909 \\
\hline & $\mathrm{X} 15$ & 0,755 \\
\hline \multirow{5}{*}{$\begin{array}{c}\text { Prosedur Reviu } \\
\text { \& Kontrol } \\
\text { Kualitas }\end{array}$} & $\mathrm{X} 21$ & 0,741 \\
\hline & $\mathrm{X} 22$ & 0,701 \\
\hline & $\mathrm{X} 23$ & 0,733 \\
\hline & $\mathrm{X} 24$ & 0,718 \\
\hline & $\mathrm{X} 25$ & 0,730 \\
\hline \multirow{6}{*}{$\begin{array}{l}\text { Komitmen } \\
\text { Profesional }\end{array}$} & X311 & 0,783 \\
\hline & X312 & 0,814 \\
\hline & X313 & 0,724 \\
\hline & X314 & 0,725 \\
\hline & X315 & 0,746 \\
\hline & X321 & 0,743 \\
\hline $\begin{array}{l}\text { Konstruk } \\
\text { Eksogen }\end{array}$ & Indikator & $\begin{array}{c}\text { Loading } \\
\text { factor }\end{array}$ \\
\hline \multirow{10}{*}{$\begin{array}{l}\text { Komitmen } \\
\text { Profesional }\end{array}$} & X322 & 0,817 \\
\hline & X323 & 0,835 \\
\hline & X324 & 0,749 \\
\hline & X325 & 0,738 \\
\hline & X331 & 0,810 \\
\hline & X332 & 0,903 \\
\hline & X333 & 0,912 \\
\hline & X334 & 0,753 \\
\hline & X335 & 0,885 \\
\hline & X336 & 0,842 \\
\hline
\end{tabular}




\begin{tabular}{|c|c|c|}
\hline \multirow{4}{*}{$\begin{array}{c}\text { Komitmen } \\
\text { Profesional }\end{array}$} & $\mathrm{X} 311$ & 0,872 \\
\cline { 2 - 3 } & $\mathrm{X} 312$ & 0,850 \\
\cline { 2 - 3 } & $\mathrm{X} 313$ & 0,878 \\
\cline { 2 - 3 } & $\mathrm{X} 314$ & 0,869 \\
\cline { 2 - 3 } & $\mathrm{X} 315$ & 0,822 \\
\cline { 2 - 3 } & $\mathrm{X} 321$ & 0,886 \\
\cline { 2 - 3 } & $\mathrm{X} 322$ & 0,834 \\
\hline
\end{tabular}

Berdasarkan hasil pengujian pada table diatas semua nilai Loading factor indikator konstruk eksogen tekenan waktu, prosedur reviu \& control kualitas, komitmen professional, dan profesionalisme memiliki hasil $>0,50$ sehingga tidak ada indikator yang harus dikeluarkan dari model.

Tabel 2 Nilai Loading factor Konstruk Endogen Penghentian Prematur atas Prosedur Audit (Sumber: hasil olah data)

\begin{tabular}{|c|c|c|}
\hline $\begin{array}{l}\text { Konstruk } \\
\text { Eksogen }\end{array}$ & Indikator & Loading factor \\
\hline \multirow{9}{*}{$\begin{array}{l}\text { Penghentian } \\
\text { Prematur atas } \\
\text { Prosedur } \\
\text { Audit }\end{array}$} & Y11 & 0,924 \\
\hline & Y12 & 0,822 \\
\hline & Y13 & 0,858 \\
\hline & Y14 & 0,846 \\
\hline & Y15 & 0,808 \\
\hline & Y16 & 0,895 \\
\hline & Y17 & 0,832 \\
\hline & Y18 & 0,869 \\
\hline & Y19 & 0,809 \\
\hline
\end{tabular}

Berdasarkan hasil pengujian pada tabel diatas, semua nilai loading factor indikator konstruk endogen penghentian prematur atas prosedur audit memiliki hasil $>0,50$ sehingga tidak ada indikator yang harus dikeluarkan dari model.

b. Average Variance Extracted

Average Variance Extracted digunakan untuk menguji apakah terdapat korelasi lebih besar dari setiap konstruk laten (Grefen dan Straub, 2005: 94). Selain itu, nilai AVE digunakan sebagai syarat validitas diskriminan tercapai (Wijayanto, 2008: 66). Nilai AVE minimum untuk menyatakan bahwa keandalan telah tercapai adalah sebesar 0,50 (Wijayanto, 2008: 66). Nilai AVE dibawah 0,50 menunjukkan bahwa indikator memiliki rata-rata tingkat kesalahan yang lebih tinggi.

Tabel 3 Hasil Uji Average Variance Extracted

(Sumber: hasil olah data)

\begin{tabular}{|l|c|c|c|c|}
\hline & $\begin{array}{c}\text { Cronbach's } \\
\text { Alpha }\end{array}$ & rho_A & $\begin{array}{c}\text { Composite } \\
\text { Reliability }\end{array}$ & $\begin{array}{c}\text { Average Variance } \\
\text { Extracted (AVE) }\end{array}$ \\
\hline $\begin{array}{l}\text { Penghentian Prematur atas Prosedur } \\
\text { Audit (Y) }\end{array}$ & 0,954 & 0,963 & 0,960 & 0,726 \\
\hline Tekanan Waktu (X1) & 0,924 & 0,932 & 0,943 & 0,769 \\
\hline $\begin{array}{l}\text { Prosedur Reviu dan Kontrol } \\
\text { Kualitas (X2) }\end{array}$ & 0,779 & 0,790 & 0,847 & 0,525 \\
\hline Komitmen Profesional(X3) & 0,962 & 0,969 & 0,966 & 0,641 \\
\hline Profesionalisme (X4) & 0,948 & 1,088 & 0,952 & 0,738 \\
\hline
\end{tabular}

Tabel di atas menunjukkan validitas konvergen yang sudah memadai, karena nilai AVE dari sebagian besar variabel lebih dari 0,5. 


\section{Uji Reliabilitas}

Menurut Ghozali (2012, h.47) realibilitas merupakan alat ukur untuk mengukur suatu kuesioner yang merupakan indikator dari variabel. Suatu kues ioner dikatakan reliabel dan handal jika jawaban dari responden terhadap pernyataan dan pertanyaan yang diajukan adalah konsisten atau stabil dari waktu ke waktu. Uji reliabilitas dalam penelitian ini menggunakan 2 metode, yaitu:

a. Cronbach's Alpha

Cronbach's Alpha digunakan untuk mengukur tingkat keandalan indikator-indikator yang digunakan dalam kuesioner penelitian (McDaniel dan Gates, 2013:289). Teknik ini dapat mendeteksi indikator-indikator yang tidak konsisten (Malhotra, 2012: 289). Nilai tingkat keandalan Cronbach's Alpha minimum adalah 0,70 (Eisingerich dan Rubera, 2010: 27).

\section{b. Composite reliability}

Composite Reliability digunakan untuk menguji reliabilitas suatu konstruk. Composite reliability dikatakan memenuhi composite reliability jika memiliki nilai composite reliability $\geq 0,70$, (Hair, 2008). Sedangkan reliabilitas 0,60 sampai dengan 0,70 masih dapat diterima dengan syarat validitas indikator dalam model baik, Imam Ghozali (2008).

Tabel 4 Hasil Uji Cronbach's Alpha \& Composite reliability (Sumber: hasil olah data)

\begin{tabular}{|l|c|c|}
\hline & $\begin{array}{c}\text { Cronbach's } \\
\text { Alpha }\end{array}$ & $\begin{array}{c}\text { Composite } \\
\text { Reliability }\end{array}$ \\
\hline $\begin{array}{l}\text { Penghentian Prematur atas Prosedur } \\
\text { Audit (Y) }\end{array}$ & 0,954 & 0,960 \\
\hline Tekanan Waktu (X1) & 0,924 & 0,943 \\
\hline $\begin{array}{l}\text { Prosedur Reviu dan Kontrol } \\
\text { Kualitas (X2) }\end{array}$ & 0,779 & 0,847 \\
\hline Komitmen Profesional(X3) & 0,962 & 0,966 \\
\hline Profesionalisme (X4) & 0,948 & 0,952 \\
\hline
\end{tabular}

Dari tabel diatas dapat disimpulkan bahwa variabel-variabel dalam penelitian ini dikatakan andal (reliabel) karena nilai original sample lebih besar dari 0,6. Dan nilai composite reliability dari setiap variabel penelitian memiliki nilai lebih dari 0.70. Dengan demikian dapat disimpulkan bahwa masing-masing variabel telah memenuhi composite reliability.

3. Pengujian Model Structural (Inner Model)

a. Analisa Pengaruh Antar Konstruk

Tahap berikutnya melihat pengaruh yang terjadi antar konstruk. Path coefficient yang dihasilkan dari SmartPLS dapat menilai dari pengaruh hasil antar konstruk.

Tabel 5 Nilai Path Coefficient

(Sumber: hasil olah data)

\begin{tabular}{|l|c|c|c|}
\hline & $\begin{array}{c}\text { Nilai } t \text { - } \\
\text { statistics }\end{array}$ & $\begin{array}{c}\text { Nilai } \text { t-tabel } \\
(\alpha=0,05)\end{array}$ & Signifikansi \\
\hline $\begin{array}{l}\text { Tekanan Waktu }\left(\mathrm{X}_{1}\right) \rightarrow \text { Penghentian } \\
\text { Prematur atas Prosedur Audit }(\mathrm{Y})\end{array}$ & 22,339 & 1,96 & Signifikan \\
\hline
\end{tabular}


REVIU \& KONTROL KUALITAS, PROFESIONAL KOMITMEN,

DAN PROFESIONALISME TERHADAP PENGHENTIAN

PREMATUR ATAS PROSEDUR AUDIT (STUDI EMPIRIS PADA

INTERNAL AUDITOR DI PERUSAHAAN DKI JAKARTA TAHUN 2017)

\begin{tabular}{|l|c|c|c|}
\hline $\begin{array}{l}\text { Prosedur Reviu \& Kontrol Kualitas } \\
\left(\mathrm{X}_{2}\right) \rightarrow \text { Penghentian Prematur atas } \\
\text { Prosedur Audit (Y) }\end{array}$ & 1,161 & 1,96 & Tidak Signifikan \\
\hline $\begin{array}{l}\text { Komitmen Profesional }\left(\mathrm{X}_{3}\right) \rightarrow \\
\begin{array}{l}\text { Penghentian Prematur atas Prosedur } \\
\text { Audit (Y) }\end{array}\end{array}$ & 0,049 & 1,96 & Tidak Signifikan \\
\hline $\begin{array}{l}\text { Profesionalisme }\left(\mathrm{X}_{4}\right) \rightarrow \text { Penghentian } \\
\text { Prematur atas Prosedur Audit (Y) }\end{array}$ & 0,118 & 1,96 & $\begin{array}{c}\text { Tidak } \\
\text { Signifikan }\end{array}$ \\
\hline
\end{tabular}

Dari hasil pengujian path coefficient Tekanan Waktu $\left(\mathrm{X}_{1}\right) \rightarrow$ Penghentian Prematur atas Prosedur Audit (Y) memiliki nilai 22,339 yang lebih besar dari t-table yaitu sebesar 1,96 sehingga dapat diberi kesimpulan bahwa Tekanan Waktu berpengaruh pada Penghentian Prematur atas Prosedur Audit pada tingkat signifikasi 5\%.

Dari hasil pengujian path coefficient Prosedur Reviu \& Kontrol Kualitas $\left(\mathrm{X}_{2}\right) \rightarrow$ Penghentian Prematur atas Prosedur Audit (Y) memiliki nilai 1,161 yang lebih kecil dari t-table yaitu sebesar 1,96 sehingga dapat diberi kesimpulan bahwa Prosedur Reviu \& Kontrol Kualitas tidak berpengaruh pada Penghentian Prematur atas Prosedur Audit pada tingkat signifikasi $5 \%$.

Dari hasil pengujian path coefficient Profesionalisme $\left(\mathrm{X}_{4}\right) \rightarrow$ Penghentian Prematur atas Prosedur Audit (Y) memiliki nilai 0,049 yang lebih besar dari t-table yaitu sebesar 1,96 sehingga dapat diberi kesimpulan bahwa tidak berpengaruh pada Penghentian Prematur atas Prosedur Audit pada tingkat signifikasi 5\%.

Dari hasil pengujian path coefficient Komitmen Profesional $\left(\mathrm{X}_{3}\right) \rightarrow$ Penghentian Prematur atas Prosedur Audit (Y) memiliki nilai 0,118 yang lebih kecil dari t-table yaitu sebesar 1,96 sehingga dapat diberi kesimpulan bahwa Komitmen Profesional tidak berpengaruh pada Penghentian Prematur atas Prosedur Audit pada tingkat signifikasi 5\%

\section{b. Uji R Square $\left(\mathrm{R}^{2}\right)$}

Nilai $\mathrm{R}^{2}$ digunakan untuk mengukur tingkat variasi perubahan variabel independen terhadap variabel dependen. Semakin tinggi nilai $\mathrm{R}^{2}$ berarti semakin baik model prediksi dari model penelitian yang diajukan. Menurut Hair, Ringle, \& Sartedt (2011), nilai R square untuk diatas 0,75 memiliki pengaruh yang kuat, 0,5 - 0,74 memiliki pengaruh sedang dan 0,25 - 0,49 memiliki pengaruh yang lemah.

Tabel 6 Nilai R-square $\left(\mathrm{R}^{2}\right)$

(Sumber: hasil olah data)

\begin{tabular}{|c|c|}
\hline Konstruk Endogen & R-square \\
\hline Penghentian Prematur atas Prosedur Audit (Y) & 0,785 \\
\hline
\end{tabular}

c. Uji F Square $\left(\mathrm{f}^{2}\right)$

Pengukuran efek (effect size) $\mathrm{f}^{2}$ adalah mengukur dampak dari konstruk predikator tertentu pada konstruk endogen. Pengukuran ini digunakan untuk mengevaluasi apakah konstruk prediktor jika dihilangkan akan memiliki dampak besar pada nilai-nilai $\mathrm{R}^{2}$ dari konstruk-konstruk endogen. Panduan untuk menilai nilai $\mathrm{f}^{2}$ untuk konstruksi laten eksogen dalam memprediksi konstruk endogen yaitu 0,02 untuk ukuran efek kecil, 0,15 untuk ukuran efek sedang dan 0,35 untuk ukuran efek besar. (Cohen, 1988).

Tabel 7 Nilai f-square

(Sumber: hasil olah data)

\begin{tabular}{|c|c|}
\hline & Penghentian Prematur atas \\
& Prosedur Audit (Y) \\
\hline
\end{tabular}




\begin{tabular}{|l|c|} 
Tekanan Waktu $\left(\mathrm{X}_{1}\right)$ & 2,833 \\
\hline $\begin{array}{l}\text { Prosedur Reviu \& Kontrol } \\
\text { Kualitas }\left(\mathrm{X}_{2}\right)\end{array}$ & 0,016 \\
\hline Komitmen Profesional $\left(\mathrm{X}_{3}\right)$ & 0,000 \\
\hline Profesionalisme $\left(\mathrm{X}_{4}\right)$ & 0,000 \\
\hline
\end{tabular}

1) Ukuran Tekanan Waktu terhadap Penghentian Prematur atas Prosedur Audit

Dari Tabel diatas, dapat disimpulkan bahwa konstruk tekanan waktu memiliki dampak yang besar pada nilai $\mathrm{R}^{2}$ konstruk penghentian prematur atas prosedur audit yaitu sebesar 2,833.

2) Ukuran Prosedur Reviu \& Kontrol Kualitas terhadap Penghentian Prematur atas Prosedur Audit

Dari Tabel diatas, dapat disimpulkan bahwa konstruk prosedur reviu \& kontrol kualitas memiliki dampak yang kecil pada nilai $\mathrm{R}^{2}$ konstruk penghentian prematur atas prosedur audit yaitu sebesar 0,016.

3) Ukuran Komitmen Profesional terhadap Penghentian Prematur atas Prosedur Audit

Dari Tabel diatas, dapat disimpulkan bahwa konstruk komitmen profesional memiliki dampak yang kecil pada nilai $\mathrm{R}^{2}$ konstruk penghentian prematur atas prosedur audit yaitu sebesar 0,000

4) Ukuran Profesionalisme terhadap Penghentian Prematur atas Prosedur Audit

Dari Tabel diatas, dapat disimpulkan bahwa konstruk profesionalisme memiliki dampak yang kecil pada nilai $\mathrm{R}^{2}$ konstruk penghentian prematur atas prosedur audit yaitu sebesar 0,000

\section{d. Uji Q Square $\left(\mathrm{Q}^{2}\right)$}

Stone-Geisser $\mathrm{Q}^{2}$ (Geisser, 1974) mendalilkan bahwa model harus mampu memenuhi syarat dalam memprediksi setiap indikator pada konstruk laten endogen. Nilai $\mathrm{Q}^{2}$ diperoleh dengan menggunakan prosedur blindfolding. Prosedur blindfolding hanya diterapkan untuk konstruk laten endogen yang memiliki model pengukuran reflektif. Nilai dari omission distance $(d)$ dinilai baik antara 5 sampai dengan 10 (Hair, Ringle, \& Sartedt, 2011).Untuk kategori besaran pengaruh dari Q square adalah 0.02 memiliki pengaruh kecil, 0.15 memiliki pengaruh sedang dan 0.35 untuk pengaruh besar. (Cohen, 1988)

Tabel 8 Nilai Q-Square

(Sumber: hasil olah data)

\begin{tabular}{|l|c|c|c|}
\hline & SSO & SSE & $\begin{array}{c}\mathrm{Q}^{2}(=1- \\
\text { SSE/SSO) }\end{array}$ \\
\hline $\begin{array}{l}\text { Penghentian Prematur atas } \\
\text { Prosedur Audit (Y) }\end{array}$ & 918,000 & 453,867 & 0,506 \\
\hline
\end{tabular}

Dari hasil tabel diatas dapat disimpulkan bahwa pada konstruk endogen penghenteia prematur atas prosedur audit memiliki nilai $\mathrm{Q}^{2}$ sebesar 0,506 . Hal ini menunjukan bahwa konstruk eksogen didalam penelitian ini memiliki tingkat prediksi yang baik terhadap konstruk endogen penghentian prematur atas prosedur audit karena lebih dari 0 . 


\section{KESIMPULAN DAN SARAN}

Berdasarkan hasil penelitian, penganalisisan data, dan pengamatan, dapat peneliti tarik beberapa kesimpulan atas penelitian ini yaitu:

1. Hasil pengujian hipotesis mengenai tekanan waktu berpengaruh positif terhadap penghentian prematur atas prosedur audit. Dimana hal ini menunjukkan bahwa apabila semakin tinggi tekanan waktu yang ditetapkan maka semakin tinggi internal auditor melakukan penghentian prematur atas prosedur audit. Sedangkan hasil pengujian mengenai tekanan waktu menunjukkan pengaruh signifikan terhadap penghentian prematur atas prosedur audit. Sehingga dapat ditarik kesimpulan bahwa hipotesis variabel tekanan waktu mempunyai pengaruh positif dan signifikan terhadap penghentian prematur atas prosedur audit.

2. Hasil pengujian hipotesis mengenai prosedur reviu \& kontrol kualitas berpengaruh negatif terhadap penghentian prematur atas prosedur audit. Dimana hal ini menunjukkan bahwa semakin rendah prosedur reviu \& kontrol kualitas maka semakin tinggi internal auditor dalam melakukan penghentian prematur atas prosedur audit. Sedangkan hasil pengujian mengenai prosedur reviu \& kontrol kualitas menunjukkan pengaruh tidak signifikan terhadap penghentian prematur atas prosedur audit. Sehingga dapat ditarik kesimpulan bahwa hipotesis variabel prosedur reviu \& kontrol kualitas mempunyai pengaruh negative dan tidak signifikan terhadap penghentian prematur atas prosedur audit.

3. Hasil pengujian hipotesis profesional komitmen berpengaruh negatif terhadap penghentian prematur atas prosedur audit. Dimana hal ini menunjukkan bahwa semakin tinggi profesional komitmen maka semakin tinggi kemungkinan auditor dalam melakukan penghentian prematur atas prosedur audit. Sedangkan hasil pengujian terhadap profesional komitmen menunjukkan bahwa variabel tidak signifikan terhadap penghentian prematur atas prosedur audit Sehingga dapat ditarik kesimpulan bahwa hipotesis variabel profesional komitmen tidak berpengaruh signifikan terhardap penghentian prematur atas prosedur audit.

4. Hasil pengujian hipotesis profesionalisme berpengaruh negatif terhadap penghentian prematur atas prosedur audit. Dimana pada saat auditor memiliki profesionalisme yang rendah, maka kecenderungan internal auditor untuk mengabaikan atau tidak melakukan prosedur audit akan semakin tinggi. Sedangkan hasil pengujian terhadap profesionalisme menunjukkan pengaruh tidak signifikan terhadap penghentian prematur atas prosedur audit. Sehingga dapat ditarik kesimpulan bahwa variabel profesionalisme berpengaruh negatif dan tidak signifikan terhadap penghentian prematur atas prosedur audit.

\section{REFERENSI}

Agoes, S. \& I Cenik Ardana. (2009). Etika Bisnis dan Profesi: Tantangan Membangun Manusia Seutuhnya. Jakarta: Salemba Empat.

Agoes, Sukrisno. (2012). Auditing: Petunjuk Praktis Pemeriksaan Akuntan Oleh Akuntan Publik. Edisi Keempat. Jakarta: Salemba Empat.

Aini, F. A. N. \& Kurnia (2015). Pengaruh Tekanan Waktu, Tidakan Supervisi, Locus of Control Terhadap Penghentian Prematur. Jurnal Ilmu \& Riset Akuntansi, 4(3), 118. 
Andani, N. M. S. \& I. M. Mertha (2014). Pengaruh Time Pressure, Audit Risk, Professional commitment dan Locus of Control pada Penghentian Prematur Prosedur Audit. E-Jurnal Akuntansi Universitas Udayana, 6(2), 185-196.

Arens, Alvin A., Elder, Randal J., Beasley, Mark S. \& E. Hogan Chris (2017). Auditing and Assuramce Services. Edisi Keenam Belas. England: Pearson Education Limited.

Budiman, N. A. (2013). Pengaruh Faktor Internal dan Eksternal Auditor Terhadap Penghentian Prematur Atas Prosedur Audit (Studi Empiris pada Kantor Akuntan Publik di Jawa Tengah dan Daerah Istimewa Yogyakarta). Jurnal Dinamika Ekonomi \& Bisnis, 10(2), 126-145.

Ikatan Akuntansi Indonesia (2015). SPAP (Standar Profesional Akuntan Publik). Jakarta: Salemba Empat.

Indarto, S. L. (2011). Analisis Faktor-Faktor yang Mempengaruhi Penghentian Prematur atas Prosedur Audit. Dinamika Sosisal Ekonomi, 7(2), 197-210.

Qurrahman, T., Susfayetti, \& A. Mirdah (2012). Pengaruh Time Pressure, Risiko Audit, Materialitas, Prosedur Review dan Kontrol Kualitas, Locus of Control serta Komitmen Profesional Terhadap Penghentian Prematur Prosedur Audit (Studi Empiris pada KAP di Palembang). E-Jurnal BINAR AKUNTANSI, 1(1), 23-32.

Wahyudi, I., J. Lucyanda, \& L. H. Suhud (2011). Praktik Penghentian Prematur Atas Prosedur Audit. Media Riset Akuntansi, 1(2).

Woolfolk, A. (2007). Educational psychology, 10 th edition. Boston, MA: Allyn \& Bacon. 